\title{
Project Performance Indicators for Measuring Construction Performance in Mumbai
}

\author{
Monika Meshram ${ }^{1}$; Rachel Gitty²; Vinay M. Topkar Ph.D ${ }^{3}$ \\ Civil and Environmental Engineering Department, Veermata Jijabai Technological Institute, \\ Mumbai, India.
}

\begin{abstract}
The aim of the study is to evaluate and rank a range of performance indicators that industrial experts regard as important, with the key identified indicators being those associated with the overall project characteristics. This paper presents the result of survey of indicators for measuring the performance of construction projects in Mumbai. A list of performance indicators is prepared based on a comprehensive literature review. These indicators grouped under 11 categories denoted as Key Performance Indicators are used to develop a survey questionnaire and RII is subsequently used to analyze the survey results and determine the relative importance and rankings of various PIs. The results reveal that the top Key Performance Indicators to evaluate the success of construction projects (in descending order) are- cost, time, safety, productivity, satisfaction, quality, knowledge and service.
\end{abstract}

Keywords - Performance Indicators; Project monitoring; Key performance indicators; cost; Quality; Relative importance index.

\section{INTRODUCTION}

Performance measurement is integral to any project and provides a basis for continuous improvement in performance. Highly competitive nature of the construction industry and profound technological changes are forcing construction executives to continuously improve the performance of their projects. It is commonly accepted that project success is measured by the performance of a project in terms of cost, time and quality [1].

The construction sector is labour-intensive, including indirect jobs, provides employment to millions of people. Considering the variety of construction projects across various sectors of economy like energy, housing, transport etc., it is necessary to identify a set of common indicators and develop a measurement scale to standardize the measures of construction project performance.

\section{OBJECTIVE OF RESEARCH}

The aim of the research presented is to assess the project performance process for its efficiency. This study will forward references for improvement of process based on conclusions of the study. Key Performance Indicators (KPI) are identified from the research work considering the working of Indian construction industry. The study also provides indications to effect improvements in the existing work patterns.

According to [2], "performance measurement is the heart of ceaseless improvement. As a general rule, benchmarking is the next step to improve efficiency and effectiveness of products and processes." Previous studies by [3], [4], [5],[6] describes project success and associated key performance indicators. However, a pertinent question is how success/ performance can be measured to effectively test the validity of proposed performance measurement system. This is because of the long timescales involved in real-life projects and possible influence of control actions taken by project management between the various processes [7].

A Key Performance Indicator is the measure of performance of an activity that is crucial to the success of an organization. They are compilation of data measures used to assess the performance of a construction process [8].

The purpose of KPI is to deliver projects: on time, on budget, free from defects, efficiently and safely by profitable companies. [2] has identified seven indicators of performance - capital cost, construction time, predictability, defects, accidents, productivity and turnover $\&$ profits.

[9] developed KPIs Framework for the UK construction industry with seven groups. These are: time, cost, quality, client satisfaction, client changes, business performance and health \& safety. [10] identifies eight KPIs for all construction as follows: (1) client satisfaction - product, service and value for money(2) defects; (3) predictability (cost and time); (4) profitability; (5) productivity; (6) safety; (7) construction cost; and (8) construction time. [11]) investigated project management (PM) practices adopted by Singaporean construction firms. The study finds that certain practices do affect project performance. The most important of these are the practices relating to scope management, such as controlling the quality of the contract document, quality of response to be perceived, variations and extent of changes to the contract.

Performance measurement is integral to performance management and provides a basis for performance improvement programs. To improve performance, organizations should both measure their performance and compare with benchmark [12].Performance measurement however does not automatically result in improved performance. These are approaches to determine if a process has obtained the desired result. Performance measurement enables organizations to identify areas in their operations where improvements are needed. 


\section{METHODOLOGY}

For the current study, performance indicators (PI) were pooled together from the literature review. Subsequently they were rationalized by merging some of them together, deleting some as they were described in different terms and some of them were split to improve accuracy of measurement. The 59 PIs were reduced to 40 for the purpose of the current study. These performance indicators were classified under 11 performance perspectives (KPIs) namely; cost, time, satisfaction, quality, people, legal, knowledge, safety, productivity, service and risk by conducting a preliminary survey from five construction industry experts including project managers, engineers and academicians. The classified 40 PIs (as shown in Table 1.1) formed the basis of questionnaire survey

The questionnaire is divided into four major parts. The first part contains questions about the details of construction firm and the respondent. The second part consists of questions pertaining to the extent, importance and mechanism of applying PIs in construction projects and the respondents were asked to rate each PIs on a five points Likert scale based on its influence on project performance. The third part contains additional comments and in fourth part, ranking the KPIs for bench marking the construction projects in Mumbai.

A total of 110 questionnaires were delivered to building construction contractors in Mumbai for the purpose of survey. Out of which 22 responses were received. Mean, standard deviation, variance and Relative importance index (RII) and the ranking of 40 performance indicators are shown in Table 1.2. Variance of each indicator was relatively small enough to conclude and the respondents agreed on its importance.

\section{RESULTS AND DISCUSSIONS}

All PIs met the requirement of reliability based on Cronbach's alpha value. Cronbach's alpha value ranging from 0.944 to 0.948 and small variances indicate that the opinions of the survey are highly consistent.

In order to identify the order of KPIs for project performance measurement, mean of PIs grouped under each KPIs were calculated and arranged in its descending order as shown in Table 1.3. Top eight KPIs were selected on the basis of cumulative percentage of its weightage. It is commonly accepted that project success is measured by the performance of a project in terms of cost, time and quality [13]. In the present study, quality is ranked as sixth important KPI.

TABLE 1.1 Classifications of KPIs.

\begin{tabular}{|c|c|c|}
\hline Sr. No. & KPIs & Performance Indicators \\
\hline 1. & Cost & $\begin{array}{c}\text { Total construction cost } \\
\text { Profitability } \\
\text { Variance cost } \\
\end{array}$ \\
\hline 2. & Time & $\begin{array}{c}\text { Total project duration } \\
\text { Schedule/Time performance }\end{array}$ \\
\hline 3. & Safety & $\begin{array}{c}\text { Health and safety } \\
\text { Recordable accident rate } \\
\text { Labour safety management } \\
\text { Lost workday case incident } \\
\end{array}$ \\
\hline 4. & Productivity & $\begin{array}{c}\text { Productivity } \\
\text { Supplier performance } \\
\text { Resource management }\end{array}$ \\
\hline 5. & Satisfaction & $\begin{array}{c}\text { Client satisfaction } \\
\text { Contractor satisfaction } \\
\text { End-user satisfaction } \\
\text { Project team/ participant satisfaction }\end{array}$ \\
\hline 6. & Quality & $\begin{array}{c}\text { Quality control } \\
\text { Quality management } \\
\text { Number of non-conformities }\end{array}$ \\
\hline 7. & Knowledge & $\begin{array}{c}\text { Staff experience } \\
\text { Contractor experience } \\
\text { Innovation and improvement/learning } \\
\text { Project management }\end{array}$ \\
\hline 8. & Service & $\begin{array}{c}\text { Environmental performance } \\
\text { Sustainability } \\
\text { Functionality } \\
\text { Site management } \\
\text { Extent of sub-contracting } \\
\end{array}$ \\
\hline 9. & People & $\begin{array}{c}\text { Motivation } \\
\text { Communication/Effective communication } \\
\text { Trust and respect } \\
\text { Harmonious working relationship } \\
\text { Employees attitude } \\
\text { Decision effectiveness } \\
\text { Long-term business relationships } \\
\text { Professional image establishment } \\
\text { Top management support }\end{array}$ \\
\hline 10. & Risk & Effectiveness of risk management \\
\hline 11. & Legal & $\begin{array}{c}\text { Claim avoidance } \\
\text { Litigation avoidance } \\
\end{array}$ \\
\hline
\end{tabular}

TABLE 1.2 Ranking of PIs

\begin{tabular}{|c|l|c|c|c|c|c|}
\hline Sr. no. & \multicolumn{1}{|c|}{ Performance Indicators } & Mean & Std. dev. & Variance & RII \% & Rank \\
\hline 1 & Total Project Duration & 4.68 & 0.57 & 0.32 & 93.64 & 1 \\
\hline 2 & Project management & 4.68 & 0.65 & 0.42 & 93.64 & 2 \\
\hline 3 & Health and safety & 4.64 & 0.79 & 0.62 & 92.73 & 3 \\
\hline 4 & Client satisfaction & 4.55 & 0.80 & 0.64 & 90.91 & 4 \\
\hline 5 & Quality control & 4.55 & 0.80 & 0.64 & 90.9 & 5 \\
\hline 6 & Total Construction Cost & 4.50 & 0.60 & 0.36 & 90.00 & 6 \\
\hline 7 & Labour safety management & 4.50 & 0.91 & 0.83 & 90.00 & 7 \\
\hline 8 & Variance Cost & 4.45 & 0.80 & 0.64 & 89.09 & 8 \\
\hline
\end{tabular}




\begin{tabular}{|c|c|c|c|c|c|c|}
\hline 9 & Quality management & 4.41 & 0.85 & 0.73 & 88.18 & 9 \\
\hline 10 & Communication/ Effective communication & 4.36 & 0.90 & 0.81 & 87.27 & 10 \\
\hline 11 & Recordable accident rate & 4.36 & 0.90 & 0.81 & 87.27 & 11 \\
\hline 12 & Resource management & 4.36 & 0.73 & 0.53 & 87.27 & 12 \\
\hline 13 & End user satisfaction & 4.32 & 0.89 & 0.80 & 86.36 & 13 \\
\hline 14 & Decision effectiveness & 4.32 & 0.84 & 0.70 & 86.36 & 14 \\
\hline 15 & Top management support & 4.32 & 0.95 & 0.89 & 86.36 & 15 \\
\hline 16 & Supplier performance & 4.32 & 0.89 & 0.80 & 86.36 & 16 \\
\hline 17 & Site management & 4.32 & 0.95 & 0.89 & 86.36 & 17 \\
\hline 18 & Profitability & 4.27 & 0.83 & 0.68 & 85.45 & 18 \\
\hline 19 & Productivity & 4.27 & 0.83 & 0.68 & 85.45 & 19 \\
\hline 20 & Functionality & 4.23 & 0.75 & 0.56 & 84.55 & 20 \\
\hline 21 & Staff experience & 4.14 & 0.89 & 0.79 & 82.72 & 21 \\
\hline 22 & Project team/ Participation satisfaction & 4.09 & 0.87 & 0.75 & 81.81 & 22 \\
\hline 23 & Innovation and improvement learning & 4.09 & 0.81 & 0.66 & 81.81 & 23 \\
\hline 24 & Professional image establishment & 4.05 & 1.21 & 1.47 & 80.90 & 24 \\
\hline 25 & Environmental performance & 4.05 & 0.72 & 0.52 & 80.90 & 25 \\
\hline 26 & Effectiveness of risk management & 4.00 & 0.87 & 0.76 & 80.00 & 26 \\
\hline 27 & Sustainability & 4.00 & 0.93 & 0.86 & 80.00 & 27 \\
\hline 28 & Contractor experience & 3.95 & 0.95 & 0.90 & 79.09 & 28 \\
\hline 29 & Claim avoidance & 3.95 & 0.84 & 0.71 & 79.09 & 29 \\
\hline 30 & Extent of subcontracting & 3.95 & 0.95 & 0.90 & 79.09 & 30 \\
\hline 31 & Long term business relationships & 3.91 & 1.06 & 1.13 & 78.18 & 31 \\
\hline 32 & Schedule/ Time performance & 3.91 & 1.06 & 1.13 & 78.18 & 32 \\
\hline 33 & Motivation & 3.86 & 1.08 & 1.17 & 77.27 & 33 \\
\hline 34 & Trust and respect & 3.82 & 1.05 & 1.11 & 76.36 & 34 \\
\hline 35 & Lost workday case incident rate & 3.82 & 1.22 & 1.49 & 76.36 & 35 \\
\hline 36 & Harmonious working relationships & 3.82 & 1.05 & 1.11 & 76.36 & 36 \\
\hline 37 & Number of non-conformities in audits & 3.82 & 0.91 & 0.82 & 76.36 & 37 \\
\hline 38 & Litigation avoidance & 3.73 & 1.12 & 1.26 & 74.54 & 38 \\
\hline 39 & Contractor satisfaction & 3.73 & 0.94 & 0.87 & 74.54 & 39 \\
\hline 40 & Employees attitude & 3.68 & 1.17 & 1.37 & 73.63 & 40 \\
\hline
\end{tabular}

TABLE 1.3 Ranking of KPIs

\begin{tabular}{|c|c|c|c|c|}
\hline KPIs & Mean & $\%$ weightage & Cumulative weightage & Rank \\
\hline Cost & 4.40 & 9.516 & 9.516 & 1 \\
\hline Time & 4.37 & 9.450 & 18.966 & 2 \\
\hline Safety & 4.33 & 9.364 & 28.330 & 3 \\
\hline Productivity & 4.31 & 9.321 & 37.651 & 4 \\
\hline Satisfaction & 4.27 & 9.234 & 46.885 & 5 \\
\hline Quality & 4.24 & 9.170 & 56.055 & 6 \\
\hline Knowledge & 4.15 & 8.975 & 65.030 & 7 \\
\hline Service & 4.15 & 8.975 & 74.005 & 8 \\
\hline People & 4.11 & 8.888 & 82.893 & 9 \\
\hline Risk & 4.07 & 8.802 & 91.695 & 10 \\
\hline Legal & 3.84 & 8.304 & 99.999 & 11 \\
\hline Sum & 46.24 & 99.999 & & \\
\hline
\end{tabular}




\section{.5. CONCLUSION}

The study indicates that the performance measurement though essential is not an easy task for construction projects considering the number of indicators involved and data that needs to be collected on continuous basis for reasonable and acceptable levels of accuracy. Based on ranking of KPIs, only few of the top ranking indicators can be used to assess the performance to make the task easier. Considering importance of each of these indicators, a weighed indicator can also be developed to indicate the performance in one single number. Individual indicator level measurements will help to make corrective actions to keep project on track.

\section{REFERENCES:}

[1]. Chan C., Albert P., David Scott and Edmond W. M. Lam,"Framework of Success Criteria for Design-Build Projects", Journal of Management in Engineering, Vol 18, pg 120-128, 2002.

[2]. Lee, S., Thomas, S.R. \& Tucker, R.L., "The relative impacts of selected practices on project cost and schedule. Construction Management and Economics,2005, 23(5), pp.545-553

[3]. Sir John Egan "Rethinking Construction" The report of the Construction Task Force to the Deputy Prime Minister, John Prescott, UK construction, 1998.

[4]. Toor, S.-U.-R.,Ogunlana, S.O, Beyond the "Iron Triangle": Stakeholder Perception of Key Performance Indicators (KPIs) for Large-Scale Public Sector Development Projects. International Journal of Project Management, 28, 228-236, 2010. http://dx.doi.org/10.1016/j.ijproman.2009.05.005.

[5]. Hany Abd Elshakour M.Ali, Ibrahim A. Al-Sulaihi, Khalid S. AlGahtani(2013) "Indicators for measuring performance of building construction companies in Kingdom of Saudi Arabia",Journal of King Saud University- Engineering Sciences 25, 125-134

[6]. John F. Y. Yeung; Albert P. C. Chan; Daniel W. M. Chan; Y. H. Chiang; and Huan Yang,"Developing a Benchmarking Model for Construction Projects in Hong Kong."Journal of Construction Engineering and Management”, 2013, Vol. 139, pp. 705-716.

[7]. Tatsiana Haponava; Saad Al-Jibouri. "Proposed System for Measuring Project Performance Using Process-Based Key Performance Indicators." Journal of Management in Engineering, 2012, Vol 28, pp 140-149.

[8]. Robert F. Cox; Raja R. A. Issa; and Dar Ahrens "Management's Perception of Key Performance Indicators for Construction." Journal of Construction Engineering and Management, 2003, Vol 129 , pp. 142-151.

[9]. KPI working group report, "KPI Report for The Minister for Construction." UK 2000

[10] Constructing Excellence, KPI Annual report 2010 https://constructingexcellence.org.uk/kpi-annual-report-2010/

[11]. Florence Yean Yng Ling, Sui Pheng Low, Shou Qing Wang, Hwee Hua Lim, "Key management practices affecting Singaporean firms' project performance in China. International Journal of Project Management” 2008, 27(1), 59-71

[12]. S.M Beatham, C.J Anumba, A. Thorpe, I.W Hedges, KPI's - a critical appraisal of their use in construction benchmarking"- An Internationl journal, 2004, 11 (1), pp. 93-117

[13]. Albert P.C, Chan, Ada P.L. Chan, (2004) "Key performance indicators for measuring construction success", Benchmarking: An International Journal, Vol. 11 Issue: 2 , pp.203-221. 